\title{
Studies on Post-Harvest Fungal Pathogens of Papaya Fruits (Carica papaya L.)
}

\author{
Vivek Kadam*, Prasad Bankar, Anuradha Bhosale, Sandhya Shitole, \\ Sourabh Chandankar, Sujit Wagh, Rupali Chitale and M.B. Kanade
}

P. G. Research Center, Department of Botany, Tuljaram Chaturchand College of Arts, Science and Commerce, Baramati, Dist. Pune - 413 102, Maharashtra, India

*Corresponding author

\section{A B S T R A C T}

Keywords

Papaya (Carica papaya L.), Fungal pathogens, Fungal diseases

\section{Article Info}

Accepted:

17 June 2019

Available Online:

10 July 2019
Present investigation focusing on the post-harvest fungal pathogens, fungal diseases and economic losses of papaya fruits (Carica papaya L.). Matured, ripened and infected fruits of papaya were subjected to isolation of their associated fungal pathogens. Fruit bating method was followed for isolation of fungi from infected papaya fruits. Total 10 fungal genera and 12 species viz. Aspergillus flavus, Alternaria alternata, Alternaria sp., Mucor mucedo, Rhizopus stolonifer, Fusarium thapsinum, Fusarium chlamydosporum, Helminthosporium cassiicola, Colletotrichum gloeosporioides, Penicillium chrysogenum, Psathyrella candolleana and Ascochyta graminicola were reported as post-harvest fungal pathogens of papaya fruits.

\section{Introduction}

Papaya (Carica papaya L.) is cultivated in tropical and subtropical regions of all over the world (Baiyewu et al., 2007). In India it is largely cultivated in Andhra Pradesh, Karnataka and Maharashtra. Due to its high nutritional values it is major and economically important fruit crop of India. It also widely used in pharmaceuticals, nutraceuticals, cosmetics and beverage industries (Aravind et al., 2013). After harvesting, during storage and transportation these fruits are subjected to several biotic and abiotic stresses (Bhale, 2011), which plays a pivotal role in association of different pathogens and establishment of diseases over papaya fruits. Among these, the fungal pathogens causes several diseases to papaya fruits for example Rhizopus rot, Aspergillus rot, Penicillium rot (Sharma, 2015), Fusarium rot, Alternaria rot and Anthracnose (Singh et al., 2012).

Fungal infection affected on quality and quantity of the fruits (Rathod and Chavan, 2012), which decreases the market value of fruits and ultimately hampers its economy (Singh et al., 2012). Considering these things, present attempt has been emphasizing on study of post-harvest fungal pathogens, fungal 
diseases, their incidence and economic loss of papaya fruits from Baramati area of Pune district of Maharashtra.

\section{Materials and Methods}

Matured, ripened and infected fruits of papaya were collected from local fruit markets of Baramati (Dist. Pune, Maharashtra, India) at an interval of one week during the study period December 2017 to January 2019. Fruits were brought to laboratory using sterilized polythene bags.

Fruit bating method was followed for isolation of fungi from infected papaya fruits. In which infected part of fruits were cut into small pieces and inoculated on Potato Dextrose Agar medium $(6.5 \mathrm{pH})$ plates in aseptic conditions (Rahman et al., 2008, Bhale, 2011 and Gadgile, 2017). These plates were incubated at room temperature for 7 days in fungal incubation chamber. During the incubation period the fungal growth was observed regularly and observations were noted.

After incubation period the photographs of plates were taken for comparative study of fungal colonies. Size, shape, structure, number and colour of colonies were also recorded. Isolated fungal colonies were used for preparation of slides. The slides were prepared by using cotton blue stain and lactophenol as a mounting medium. Slides were observed under light microscope and microphotography was also done. Fungi were identified on the basis of morphological characters of spores and using standard literature. Ainsworth's (1973) classification was used for classification of isolated and identified fungi.

\section{Results and Discussion}

In the present study total 10 fungal genera and 12 species were noticed as the pathogenic fungi to papaya fruits. They were identified on the basis of morphological characters, spores structure and fruiting bodies. Aspergillus flavus, Alternaria alternata, Alternaria sp., Mucor mucedo, Rhizopus stolonifer, Fusarium thapsinum and Fusarium chlamydosporum were found frequently throughout the study. On the contrary Helminthosporium cassiicola, Colletotrichum gloeosporioides, Penicillium chrysogenum, Psathyrella candolleana and Ascochyta graminicola were reported uncommonly. The frequency of Deuteromycotina fungi were dominant (08) followed by Zygomycotina (02), Ascomycotina and Basidiomycotina (01) (Table 1).

During the investigation, majority fungi were found as pathogenic to papaya fruits. According to literature survey they causes soft rot (Fusarium and Rhizopus), fruit rot (Aspergillus), fruit spot (Alternaria), anthracnose and damping-off (Colletotrichum), blue mold rot (Penicillium) and brown spot (Helminthosporium) of papaya fruits (Nishijima, 1999). According to Gadgile (2017) Aspergillus rot, Alternaria rot and soft rot, Anthracnose and fusarial rot were reported as common fungal diseases of papaya fruits from Palam. Singh et al., (2012) reported Fusarium sp., Rhizopus sp., Aspergillus sp., Penicillium sp., Alternaria sp. and Colletotrichum sp. were common and major post-harvest pathogens of papaya fruits from Gorakhpur city. In the present study we also found similar results. Prasad and Verma (1970) noticed that Colletotrichum sp. is the most common and major post-harvest fungal pathogen of papaya fruit from Bihar (Tasiwal, 2008).

Fungal infection negatively affected on the organic and inorganic constituents of fruits and ultimately the nutritional profile of fruits becomes hampering (Singh and Sharma, 2007). Jurandi and Angela (2011) have 
noticed that, physical disorder of fruits due to unfavourable environmental factors and endogenous factors which decrease the quality and shelf life of papaya fruit. Physiological disorders are associate with biochemical changes in fruit ripening and host senescence such as host $\mathrm{pH}$, sugar content and cell-wall components, fat, carbohydrate, protein and oxidation of wounded tissue quickly responses by the infecting fungus (Oliveira et al., 2018).

Table.1 Isolated fungi from infected papaya fruits

\begin{tabular}{|c|l|l|}
\hline Sr. No. & Name of Fungus & Sub-division \\
\hline $\mathbf{1}$ & Mucor mucedo & Zygomycotina \\
\hline $\mathbf{2}$ & Rhizopus stolonifer & Zygomycotina \\
\hline $\mathbf{3}$ & Ascochyta graminicola & Ascomycotina \\
\hline $\mathbf{4}$ & Psathyrella candolleana & Basidiomycotina \\
\hline $\mathbf{5}$ & Alternaria alternata & Deuteromycotina \\
\hline $\mathbf{6}$ & Alternaria sp. & Deuteromycotina \\
\hline $\mathbf{7}$ & Aspergillus flavus & Deuteromycotina \\
\hline $\mathbf{8}$ & Colletotrichum gloeosporioides & Deuteromycotina \\
\hline $\mathbf{9}$ & Fusarium thapsinum & Deuteromycotina \\
\hline $\mathbf{1 0}$ & Fusarium chlamydosporum & Deuteromycotina \\
\hline $\mathbf{1 1}$ & Helminthosporium cassiicola & Deuteromycotina \\
\hline $\mathbf{1 2}$ & Penicillium chrysogenum & Deuteromycotina \\
\hline
\end{tabular}

Rathod and Chavan (2012) studied the sugar, pectin acid, ascorbic acid, calcium and phosphorus content from infected papaya fruits and found decreasing trend compared to healthy fruits. Rhizopus stolonifer, Aspergillus falavus, Penicillium digitatum, Fusarium moniliforme were responsible for decreasing in mineral content of papaya fruits due to secretion of cell wall degrading enzyme and mycotoxin by fungal pathogens (Sawant and Gawai, 2011). Yakoby et al., (2000) had reported that, Colletotrichum gloeosporioides was expressed when the $\mathrm{pH}$ was above 5.7 that decaying tissue of ripened fruit of papaya. On the contrary Dov Prusky and Amnon Lichter (2008) noted that, Alternaria alternata found above $6.0 \mathrm{pH}$, which was characteristic of decayed tissue in ripened papaya fruit.

Alkan and Fortes (2015) reported that 30\% papaya fruits were unable to consumption due to post-harvest losses. Considering these things farmers are discourage from producing and marketing fresh fruits of papaya (Mulualem Azene et al., 2014). Incidence of insect pest, mites, rodents or from handling, physical changes or biochemical changes or by contamination of mycotoxins and pesticide residues fruit gets qualitative and quantitative losses (Dov Prusky and Amnon Lichter, 2008).

Considering in to above discussion it is concluded that, farmers and fruit sellers should aware about the proper and scientific methods of harvesting, handling, storage and transportation of papaya fruits. Thus, shelf life of fruits can be increased and quality of fruits will be maintained.

\section{Acknowledgements}

Authors are sincerely thankful to Dr. Chandrashekhar Murumkar, Principal and Head, P. G. Research Center, Department of 
Botany, Tuljaram Chaturchand College of Arts, Science and Commerce, Baramati, Dist. Pune, MS, India for his constant guidance and encouragement.

\section{References}

Alkan Noam and Fortes Ana M. (2015). Insights into molecular and metabolic events associated with fruit response to post-harvest fungal pathogens. Frontiers in Plant Science, 6(889): 114.

Aravind, G., Debjit. B., Duraivel, S. and Harish, G. (2013). Traditional and medicinal uses of Carica papaya. Journal of Medicinal Plants Studies, 1(1): 7-15.

Baiyewu, R. A., Amusa, N.A., Ayoola, O.A. and Babalola, O.O. (2007). Survey of the postharvest diseases and aflatoxin contamination of marketed pawpaw fruit (Carica papaya L.) in South Western Nigeria. African Journal of Agricultural Research, 2 (4): 178-181.

Bhale, U. N. (2011). Survey of market storage diseases of some important fruits of Osmannabad District (M.S) India. Science Research Reporter, 1(2): 88-91.

Dov Prusky and Amnon Lichter (2008). Mechanisms modulating fungal attack in post-harvest pathogen interactions and their control. European Journal of Plant Pathology, 121(3): 281-289.

Gadgile, D. P. (2017). Post-harvest fungal diseases of papaya. Bioinfolet, 14(4A): 367-368.

Jurandi Goncalves de Oliveira and Angela Pierre Vitoria (2011). Papaya: Nutritional and pharmacological characterization, and quality loss due to physiological disorders. Elsevier Ltd Food Research International, (44) 1306-1313.

Mulualem Azene, Tilahun Seyoum Workneh and Kebede Woldetsadik (2014). Effect of packaging materials and storage environment on postharvest quality of papaya fruit. Journal of Food Sciences and Technology, 51(6): 1041-1055.

Nishijima, W. T. (1999). Common Names of Diseases, The American

Phytopathological Society.

Oliveira, Jurandi and M. Mazorra Morales, Luis and Silva, Willian and Gomes Filho, Aroldo and E. Paull, Robert (2018). Postharvest physiological disorders in papaya. Postharvest Physiological Disorders in Fruits and Vegetables (Innovations in Postharvest Technology Series) 399-416.

Rahman, M.A., Mahmud T.M.M., Kadir J., Abdul Rahman, R. and Begum M.M. (2008). Major postharvest fungal disease of papaya cv. 'Sekaki' in Selangor, Malaysia. Pertanik Journal Tropical Agricultural Science, 31 (1): 27-34.

Rathod, G. and Chavan, A. M. (2012). Status of biochemical content in papaya (Carica papaya L.) after post-harvest pathogenesis by fungi. Current Botany, 3(3): 28-33.

Rawal, R. D. (2010). Fungal diseases of papaya and their management. Acta Horticulturae, (851), 443-446.

Sawant, S. G. and Gawai D. U. (2011). Effect of fungal infections on nutritional value of papaya fruits. Current Botany, 2(1): 43-44.

Sharma, V. (2015). Evaluation on incidence and alternative management of postharvest fungal diseases of papaya fruit (Carica papaya L.) in Western U.P. International Journal of Theoretical \& Applied Sciences, 7(1): 6-12.

Singh, D. and Sharma R. R. (2007). Postharvest diseases of fruit and vegetables and their management. In Prasad, D. (Ed.), Sustainable Pest Management. Daya Publishing Houses, New Delhi, India. 
Singh, P., Mishra, A. K. and Tripathi, N. N. (2012). Assessment of mycoflora associated with postharvest losses of papaya fruits. Journal of Agricultural Technology, 8 (3): 961-968.

Tasiwal, V. (2008). Studies on Anthracnose A postharvest disease of papaya. Thesis submitted to the Department of Plant Pathology College of Agriculture,
Dharwad University of Agricultural Sciences, Dharwad.

Yakoby Nir, Ilana Kobiler, Amos Dinoor and Dov Prusky (2000). pH regulation of pectate, lyase secretion modulates the attack of Colletotrichum gloeosporioides on avocado fruits. Applied and Environmental Microbiology, 66(3): 1026-1030.

\section{How to cite this article:}

Vivek Kadam, Prasad Bankar, Anuradha Bhosale, Sandhya Shitole, Sourabh Chandankar, Sujit Wagh, Rupali Chitale and Kanade, M.B. 2019. Studies on Post-Harvest Fungal Pathogens of Papaya Fruits (Carica papaya L.). Int.J.Curr.Microbiol.App.Sci. 8(07): 2176-2180. doi: https://doi.org/10.20546/ijcmas.2019.807.263 